\title{
BRATISLAVSKÁ THEATRE - PERFORMANCE "YOU NEVER KNOW": FORUM THEATRE ON THE TOPIC OF HOMELESSNESS - ACCORDING TO AUGUSTO BOAL AND HIS THEATRE OF THE OPPRESSED
}

\author{
Markéta Zelená
}

\begin{abstract}
The text discusses the theoretical delimitation and practical use of the method of the Theatre of the Oppressed, invented by Augusto Boal, a Brazilian dramatist. The method makes use of dramatic means to process and seek ways to overcome social problems of different groups in the society. Specifically, the text deals with the use of one of its techniques - the Forum Theatre - when working with a group of people who have their own experience with homelessness, in connection of the presentation of the phenomenon through an interactive theatre performance to a broader public. The project was created in the Centre of Services for Homeless People of the Brno Diocesan Charity where a group of about eight people met from autumn 2014 to spring 2015. The group went creating a story concerning the problems faced by homeless people and based on their own life experience. When the work was finished, some interactive performances took place, culminating in November 2015 at the Night Outside, which is an event supporting homeless people.
\end{abstract}

\section{Keywords}

Theatre of the Oppressed, Forum Theatre, homeless people, homelessness

\section{Theatre of the Oppressed and Forum Theatre - its basis and its essence}

The Theatre of the Oppressed refers to the philosophical concept of the pedagogy of the oppressed, developed by Paulo Freire in the 1960s in Brazil in response to the elitist and later military political regime. It is aimed at developing critical thinking in 
people through a dialogue in which they have the opportunity to speak about their life problems and thus get insight into their own situation in a broader context. But the pedagogy of the oppressed goes further; it also tries to search ways for people to change actively their own situation in real life, within different social movements (Freire, 1996; Remsová, 2016).

The approach of the pedagogy of the oppressed is also the base for the Theatre of the Oppressed of Augusto Boal, the Brazilian dramatist who developed the theatre method from the 1970s. He aimed, similarly to Paulo Freire, at restoring the missing dialogue among people through a theatre form that was originally intended for poor Brazilian population but that was later developed also in Europe where he emigrated from Brazil (Remsová, 2016).

The main goal of the Theatre of the Oppressed consists in asking questions concerning social problems and in using theatre techniques to overcome the respective problems in everyday life (Čermáková, 1999). The theatre emphasizes the collective nature of the problems and serves to identify the oppression mechanisms, i.e. to have a think about individual problems of persons in broader social and political context. Thanks to the Theatre of the Oppressed, we have an opportunity not only to have think about problems but to get also practical experience with overcoming them with the help of theatre techniques and to apply the experience later in our everyday life (Mazzini, 1992; Remsová, 2016). As Boal (1985) states, the main purpose of the Theatre of the Oppressed is to change the viewers into actors who come to the scene and transform the dramatic action of the story. So they become protagonists of the story and can try out different possibilities of solving the situation, they can actively discuss potential change strategies. Thus the theatre becomes a test of the strategy of change for real life. As Moree (2016) says, the force of the Theatre of the Oppressed can consist in the opportunity to try out, in draft and personally, things we may be afraid of trying in real life, and based on that, to search new creative solutions for situations that seem unsolvable at first sight.

That leads us to the main technique of the Theatre of the Oppressed we used in our case, specifically the Forum Theatre. The Forum theatre is an interactive theatre technique in which a group of actors prepare a theatre performance in which they present a situation of oppression or conflict from their everyday life, creating a story of an oppressed protagonist (Mazzini, 1992). After the performance has been played, the viewers are invited to get actively involved in it - they can intervene in the story and try different other strategies the protagonist could use in a situation of oppression. In that way, the theatre tries primarily to incite a discussion over the topic; it might not necessarily reach a solution of the given problem. It rather tries to point out the opportunity for trying the strategies also in real life and to support solidarity with the oppressed through own experience with the problematic nature of their situation (Remsová, 2016). To involve the public, the Forum Theatre has so called Joker who acts as a communicator with the public, directs the whole performance and incites the viewers to discuss and to get actively involved in the story (Pavlovská \& Remsová, 2006). 
When creating the story, we also used other techniques - dramatic plays and exercises serving to release the mind, the body and different blocks of the actors. We also used the theatre of the picture that works with creation of pictures of human bodies, using the body language for the dialogue among people and for exploration of conflict life situations (Mazzini, 1992).

\section{How the "You Never Know" and the Bratislavská Theatre company was created}

The idea of working with the method of the Theatre of the Oppressed with homeless people in the Brno Diocesan Charity emerged after I came to the Daily Centre for Homeless People when I met Mirek Strahovský, my colleague from a Reception Centre. I had got experience with the method in different foreign workshops and I also devoted my thesis to it; Mirek had organized here, together with the Atelier Theatre, interactive workshops of theatre improvisations for the clients and for the general public; so our theatre enthusiasm combined into the idea of creating the Forum Theatre on the topic of homelessness, together with a group of people who have personal experience with it. We started working with a group of six people, exploring together problematic topics from their life that were important and pressing to them and for which they would like to find a solution. The phenomenon of homelessness was a common denominator of the topics. All the time, we strived for an equal approach, based on mutual respect, dialogue among all participants and openness towards opinions and suggestions of each group member. We used different theatre plays and exercises to prepare the actors for the actual creation of scenes for our story.

The topics were brought by the actors from their own lives; so they included real stories. Nevertheless, after joint discussion, we chose topics that turned up to be stimulating for our resulting story. After that, we proceeded to elaborate each topic separately, through the theatre of the picture where everybody having own experience with the topic could use the co-actors' bodies to create a picture that represented the situation and constituted a base for our further work. After mutual discussion, we chose a resulting picture for each topic, integrating the necessary elements from different pictures into it. Further, we used theatre improvisation to elaborate the scene based on the picture, elaborating the relationships in the conflict situation, the relationships between the oppressed and the oppressor, and between different persons from the scene.

In that way, after some eight months of common work, the group Bratislavská Theatre (based on the address of our services for homeless people at Bratislavská Street in Brno) and the performance "You Never Know" were created. A story with the protagonist (male Pavel or female Pavla) who passes a labyrinth of different life situations was developed. The story starts with the runaway from home because of the violence of the drunken father against the mother; it continues through minor offences - illegal smoking at the bus stop, assessed in Pavel's case differently from the case of a municipal representative - to the effort to find a job after quite a long time of life in the street, with a criminal record, which 
seems unrealistic. The protagonist finds only an illegal job with a self-serving owner of a sawmill, who enriches himself on Pavel's expense. He continues through the story to a reception centre, and when his contract ends, he tries to find social housing that actually does not exist by law and he is passed as a hot potato among different authorities who do not know anything about him. Finally, he is caught up by arrears from the past in form of different debts that cause him to be homeless and he does not see any other solution than to attempt suicide...

We presented our performance several times before the general public, before students of social schools and before the actual homeless people. The most interesting situation emerged when we mixed viewers from all groups; different opinions and ideas on the development of our story emerged and a dialogue and joint discussion of everybody originated. With the help of the Joker, we involved the public into the discussion on the problems of homeless people; the viewers came to the scene to try different strategies for the protagonist to try out in the situations of our story. Some scenes gave us shivers; the viewers offered feedback about the force of the story and about the authentic performance of our actors.

Our actors were encouraged by the project; they felt proud to have prepared and presented a theatre play, to have managed improvisation and reaction to different strategies coming from the public. They also felt well about having shown to the public that the problem of homeless people is not only black and white and about having shared their stories. To us, it was important that we gave voice to homeless people, that we offered them an opportunity to share their problems with other people, to discuss problems of homeless people with them, and that we could work on the preparation of a performance that could incite a discussion about the topic in the public.

We played our last performance at the Night Outside in November 2015. The project seems to have made sense, although our group does not meet in the original structure any more, as some actors scattered to different places, as is common for homeless people. We keep trying to search other ways and projects to allow our clients to be actively involved in the story and to create it, which is a priority for our services. 

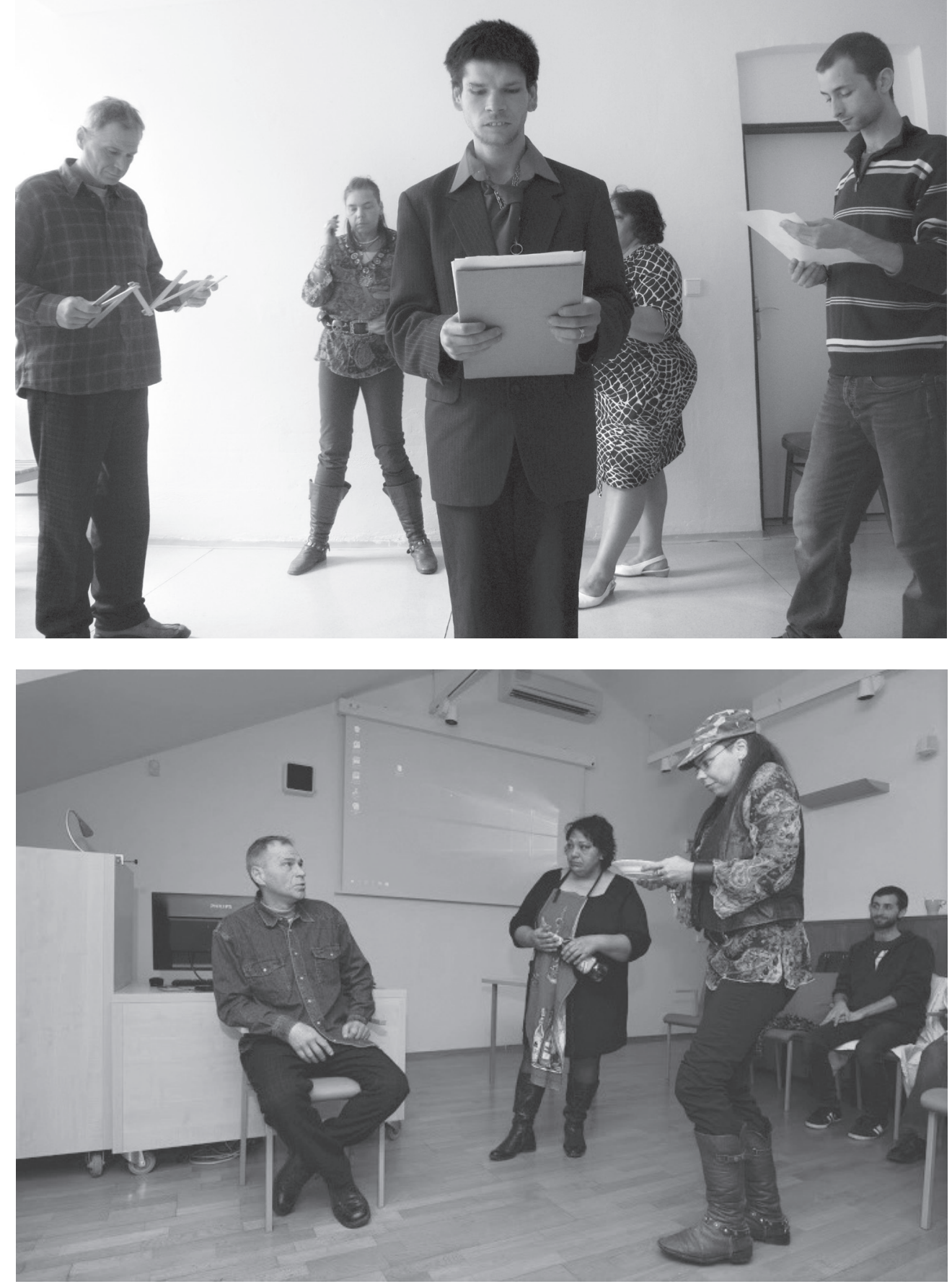


\section{References}

Boal, A. (1985). Theatre of the Oppressed. New York: Theatre Communications Group.

Čermáková, I. (1999). Augusto Boal a dramatická výchova. [Augusto Boal and Drama in Education]. Tvořivá dramatika [Creative Drama], 10(1), I-XII.

Freire, P. (1996). Pedagogy of the Oppressed. London: Penguin Group.

Mazzini, R. (1992). II teatro dell'Oppresso come strumento per l'educazione alla pace e ai diritti umani. [The Theatre of the Oppressed as a Tool for Peace Education and Human Rights]. Giolli: Amnesty International Pordeone.

Moree, D. (2016). Divadlo utlačovaných pro školy a ve školách. [Theatre of the Oppressed for Scools and in Schools]. In B. Santos, J. Boal, \& A. Boal, Divadlem ke změně: vybrané texty $k$ divadlu utlačovaných. [Theatre of Change: the Selected Texts to the Theatre of the Oppressed] (pp. 13-16). Prague: Antikomplex.

Pavlovská, M., \& Remsová, L. (eds.). (2006). Jak na divadlo fórum. [How to do Forum Theater]. Brno: MSD.

Remsová, L. (2016). Předmluva. [Preface]. In B. Santos, J. Boal, \& A. Boal, Divadlem ke změně: vybrané texty $k$ divadlu utlačovaných. [Theatre of Change: the Selected Texts to the Theatre of the Opressed] (pp. 5-11). Prague: Antikomplex.

\section{Author}

Mgr. Markéta Zelená

Diocesan Charity Brno - Low-treshold day center for homeless people

Bratislavská 58, Brno 602 00, The Czech Republic

marketa_zelena@centrum.cz 